\title{
Parent Involvement on School Committees as Social Capital to Improve Student Achievement
}

\author{
Ravik Karsidi, a, ${ }^{\text {, }}$ Rahesli Humona, ${ }^{\text {a }}$ Atik Catur Budiati, ${ }^{a}$ and Waskito Widi Wardojo ${ }^{a}$ \\ ${ }^{a}$ Sebelas Maret University, Indonesia
}

\begin{abstract}
This study explores how the participation of parents on school committees improves student achievement. In decentralized education systems like the one in Indonesia, parents' participation has become a focal point for improving the quality of education. The data for this study were collected using questionnaires distributed to 250 students in state senior high schools, selected by quota-purposive sampling. The qualitative findings of this research are threefold: most parents participated in student learning only by providing material aspects, such as tuition and books; most parents had a misconception that it was the school that should solely be responsible for the education of their children; busy parents tended to ignore the progress of their children's learning. In order to create social capital for their children, parents need to be active in the learning process, cooperate with school officials, and get involved in the planning of social activities.
\end{abstract}

\begin{abstract}
Abstrak
Penelitian ini mengupas bagaimana partisipasi orang tua melalui komite sekolah dapat meningkatkan prestasi belajar siswa. Dalam sistem pendidikan desentralisasi seperti yang berjalan di Indonesia, partisipasi orang tua menjadi faktor penting dalam peningkatan kualitas pendidikan. Data penelitian ini diperoleh menggunakan kuesioner yang disebarkan kepada 250 siswa SMA negeri, yang dipilih menggunakan prosedur quota-purposive sampling. Penelitian ini menghasilkan tiga temuan kualitatif: sebagian besar partisipasi orang tua hanya dalam bentuk pemenuhan aspek material, seperti uang sekolah dan buku; sebagian besar orangtua memiliki pemahaman yang salah bahwa sekolahlah yang harus bertanggung jawab sepenuhnya terhadap pendidikan anak; orang tua yang sibuk cenderung tidak perduli terhadap perkembangan proses belajar anak-anaknya. Untuk menciptakan modal sosial bagi anak-anaknya, orang tua perlu lebih aktif dalam proses belajar anak-anak, bekerjasama dengan pengelola sekolah, dan aktif dalam perencanaan kegiatan sosial.
\end{abstract}

Key Words: Parent Involvement, Parent Responsibility, Social Capital, School Committees

\section{Introduction}

The quality of education is influenced not only by the learning-teaching process and the infrastructure at schools, but also by the active participation of

* Corresponding author.

Address: J1. Pembangunan I/28, Perum UNS Jati, Jaten, Karanganyar, Solo, Indonesia.

Email: ravikkarsidi@yahoo.com. families and society. This is because education is a responsibility shared by the state, parents, and society. The father of education in Indonesia, Ki Hadjar Dewantara, maintained that the education process would not run well if these three components were not well-integrated. This implies that parents and society have to contribute to the process of education at schools. The active participation of parents is an indicator of good school management. In other words, good school management should also be able 
to involve parents and society in their day-to-day activities.

Stelios Georgiou (2007) finds that parents who believe that their involvement really matters will find ways to get involved. This shows that parents and society share a responsibility to take part and contribute to the learning process at schools. Parents can play their roles as audience members, volunteers, paraprofessionals, teachers, learners, and even as decision makers (Jabar 2010).

Michael Lawson and Tania Alameda-Lawson (2011) also find that social networks and parent associations can reduce students' problems. For example, it is important that parents take part when their children are doing homework. Another way that parents may influence the success of the learning process is by paying attention to the psychological and emotional states of their children. Suresh $\mathrm{Ku}-$ nar N. Vellymalay (2012) also asserts that parental involvement at home has a positive and significant influence on their children's performance at school. Children will achieve better results at school when their parents show more involvement.

Today, through the so-called decentralized education system in Indonesia, it is important that schools optimize the role of the parents. The active participation of parents depends on how the schools involve them in every aspect, not only in providing sufficient infrastructure, because parents, as well as society at large, should be the schools' partners. In many cases, parents do not know what to do and are less sensitive to their children's problems at school. This can be the result of a lack of communication between schools and parents. Due to such minimum contact, parents often have no idea about how to contribute to the success of the learning process. In some other cases, many parents believe that the success of the learning process is solely the schools' responsibility.

Most schools in Indonesia have school committees, where parents can formally take part in the planning process. Siskandar's study (2008), however, shows that the committees need to play more roles, especially in monitoring the results of the learning process. Another study suggests that the maximum involvement of parents through school committees has a positive impact on the effectiveness of the learning process at schools (Yeni 2008). Bambang Sumintono, Nora Mislan, and Hamdan Said (2013) have unfolded the perspectives and practices of school committees as an implementation of the school-based management policy. They find that this practice has devolved authority on the school level.

This article discusses the role of parents as providers of social capital to increase the success of the learning process. The discussion covers three areas: factors that prevent parental involvement in the learning process, what schools have done to build partnerships with parents, and the expected results of having partnership with parents.

\section{Literature Review}

Discussing the process of social life, Pierre Bourdieu, as cited in Haryatmoko (2003), introduces a concept of habit describing how life goes hand-inhand with social structure. This process takes place naturally in certain social environments. This is different from Emile Durkheim's (1973) thesis, which states that it is the individual who decides his or her actions and that individuals create the social structure that leads to the relationship between the structure and the individual members of society (Andreski 1989).

According to Ed Rahmana (2000), habit is a continuous disposition system that functions as a generative basis for the structured and objectively integrated praxis of life. In other words, habit is a result of learning done through nurturing, playing activities, and education. The learning process takes place smoothly and naturally, and finally leads to the institutionalization of values.

With this concept, a process of habituation should take place during the learning process at schools, to allow for a learning process to grow through the relationship between schools, families, and society.

Robertus Robet and U. Abdul Rozak (2011) identify five principles of the habituation of learning in education. First, education should create a matrix of perception based on the individual's background. Second, education should create forms 
of appreciation, teaching the learners to appreciate things. Third, education should lead the learners to action. Fourth, education should create a habit or change an old habit into a new one. Fifth, education can spring from both objective and subjective interactions.

A process of habituation needs sociocultural capital to be a part of social life. Cultural capital here refers to the social relationships in a system of meaning exchange, including the accumulation of knowledge and aesthetics that are converted to power and status. Education, for example, is a reflection of cultural capital, not because with education people can find jobs, but because education reflects a certain power and social status. Differences in education also reflect social classes (Barker 2004).

Robert Putnam (1993) defines social capital as a mutual trust between the members of society and their leaders. Social capital is an institution that includes networks, norms, and social trust that create social collaboration to meet the commonly shared needs of a society. Such a horizontal association will give both desired outcomes and undesired outcomes. Francis Fukuyama (2002) adds that the most important component in social capital is the trust that functions as the glue for all members to sustain the collaboration.

Bourdieu, as cited in Haryatmoko (2003), defines social capital as actual and potential resources that individual members get from institutionalized social networks that provide collective supports to each other. Social capital should be able to transform weak and vulnerable social relationships like those between neighbors or friends into stronger, longlasting relations, until each member feels an obligation to other members. Bourdieu also maintains that social capital is an integrated system that relates one aspect of society to another.

Bourdieu's theory places habit as a cultural theory of action combined with economic and symbolic capital. This very subjective habit is a kind of detector for an individual's to access a field. A learning habit, being a tradition in one's family, can make learners from a certain social group able to compete. Learners' success results from their disposition, skills, and practices that show a natural competency that can be developed in a certain social environments.

\section{Research Methods}

This study was conducted in five public senior high schools in Karanganyar, Central Java, Indonesia: SMAN 1 Karanganyar, SMAN 1 Kebakramat, SMAN 1 Gondangrejo, SMAN 1 Colomadu, and SMAN 1 Karangpandan. These five schools were selected so that this research covered rural areas, suburban areas, and urban areas. The data were collected through questionnaires. Fifty respondents were selected from each school, using a quota-purposive sampling technique. Focus group discussions (FGDs) involving headmasters, teachers, parents and students were conducted to confirm the data obtained from the questionnaires.

This research used an internal validity technique by correlating individuals' scores to the total score. A product moment technique was then used to identify the correlation coefficient. The data were then analyzed using a double regression analysis technique, coupled with a descriptive-qualitative analysis.

\section{Findings and Discussion}

The first finding of this research is that the intensity of parents' guidance is important. This variable received a beta coefficient of 0.098 , showing that every 1 percent increase in the intensity of parents' guidance would improve learners' achievement by 0.098 percent. This variable has the probability value of 0.022 , significant at $\alpha=5$ percent. Again, this confirms that parental guidance has a positive influence on the learning process.

This first finding warns us of the importance of parental guidance in improving the quality of education at schools. Despite the importance, most of the families in this study have not actively taken part in helping their children learn. This is mainly because most of parents do not understand the underlying significance of their role for the progress of their children at schools. In addition, their low socioeconomic status is parallel to their ignorance of their children's success in school. 
Compared to the other variables that may influence the learning results, parental guidance gives the most significant impact. The relative contribution of parental guidance was 35.41 percent. Meanwhile, the intensity of parental guidance also gives a positive effect at 4.94 percent.

Parental guidance is not limited to parents' physical presence around their children; it also refers to their continuous assistance in solving their children's problems in learning. However, there is a tendency for affluent parents to send their children to tutors for all their school subjects. They think that tutors can bridge the gap between their own level of capacity and the schools' standards, especially because the lessons are delivered in English. Such tutorial programs are available in suburban, rural, and urban areas. For such a tutorial, parents sometimes even have to pay more than their children school tuition.

One student remarked,

My lessons usually finish at 14:00. After that, I join extracurricular activities until 17:00. I am now also the chair of the student association. My parents give me enough support. At night, we invite tutors to help me study at home so that I can perform well at school. (SMAN 1 Karanganyar)

Another student said,

At school, I have many activities. After school, I go to a tutor for two hours. At home, I have another tutor help me learn until 22:00. I need to learn with a tutor because I cannot meet the demands from school myself. Moreover, the lessons are in English. My parents give me support at home, as long as I have a good rank at school. (SMAN 1 Karanganyar)

It is also worth noting that going to a tutor is not always the parents' idea. Some school committees also coordinate the use of tutors. According to one committee member,

In formal meetings with the school management team, we usually propose some activities to try to improve the quality of our children's learning, such as giving extra lessons, building good character skills, etc. Then the school committee shares the expense. (SMAN 1 Karanganyar)

It is also important that parents understand that the success of learning is not merely indicated by an increase in their children's cognitive intelligence. Intelligence should also include the capacity of learners to articulate their identities through ongoing processes. Schools should provide a conducive and integrated environment that allows individuals to support each other so that the learning process runs well. This is what is called social capital.

This finding supports Zamroni (2001) in that society's support to school should not be limited only to financial support but should also cover their involvement in improving the quality of the learning process. Mulyasa (2001) has a similar finding that parents should be involved in the learning process, including in identifying their children's talents, mental education, and cultural education. Parents should also be involved in deciding how the learning-teaching method, learning media, and the evaluation process should be used with their children.

A parents association is a supporting unit for the school infrastructure. One member said, "We do not really take part in the process of improving the quality of the learning process. The schools invite us only to discuss issues on infrastructure and facilities" (SMAN 1 Karanganyar).

Another member said, "The school sometimes invites us to discuss financial issues and the needs of the school, such as the need to build more toilets. If the schools have many needs to meet, we make priorities" (SMAN 1 Karanganyar).

The role of the school committee is also limited because the organization is not professionally managed. Most of the board members are volunteers who get no payment for what they do with the committee. The daily business activities of the parents sometimes also prevent the members of the committee from being active at the school.

Another finding is that some parents have a perception that schools are the only place for their children to become good people. In the FGDs, however, 
some parents indicated that they understood that this perception is wrong. The outside environment has an even stronger influence on their children.

This research also finds that parents who are not active in the parents association do not mean to ignore their children's activity at schools. They are informed about what the schools need from the announcements, especially about the amount of money they have to share through the association to support school activities. This amount of money is the same for all parents in each school, but it is different from one school to another, depending on the needs of the particular school and the agreement of the school management and the association committee. The average amount for each student is 160,000 IDR (US\$16), in addition to 250,000 IDR (US\$25) for maintenance or construction. In addition, parents of children in Grade 3 are also requested to pay 5,000 IDR (US\$0.5) per month for extra lessons given prior to the final national exam. Some parents claim that they have taken part in the learning process if they have paid their share. With such a misconception, therefore, schools need to talk to parents, especially about their roles in improving the learning outcomes of their children.

These findings tell us to position parents in wider and bigger roles that include at least three aspects. First, parents should be involved not only in providing school infrastructure, but they should also be active in the learning process. Second, it is important that schools maintain good partnerships with parents. Third, parents should be involved not only in the planning of school programs and activities, they should also be involved in the management of those programs. Such involvement will lead to social control in the learning process and improve learning outcomes.

Another implication is that the social capital created from the active participation of parents needs to be developed in three components: trust, networks, and shared-institutionalized values. These three components should be well integrated so that schools can provide a conducive environment for student learning.

Schools should be able to obtain the trust from the stakeholders, especially the parents. Parental participation can be based on three motivating factors. First, parents should take part so that they know the progress and the problems of their children. When parents know their children's problems, they know how to motivate them to learn as well as they can. Problems of learning should not be directed only to teachers; they also should be shared with parents. Second, parents should be able to give constructive input to policymakers at schools, especially when dealing with quality improvement. Third, transparency and openness are required so that both parents and schools can evaluate their policies and programs. These three factors will comprise a social system at schools that involves parents in mutual partnerships. This process then will lead to parental participation as social capital.

In Indonesia, as required by the Act of Education No. 20/2003, the components of education institutions include schools, education boards, school committees, and parents associations. As underlined by Made Pidarta (2004), participation will result in personal pride and confidence when all take part in the policymaking process. Participation also brings empowerment, where every party shares similar opportunities in the decision making process. In a social network, participation plays an important role because the cooperation in a community is actually a result of individual participation.

\section{Conclusions}

The finding that there is a positive correlation between parental guidance and children's achievement confirms that parents need to give more attention to their children by creating good relationships with them. This will result in a good learning environment that motivates children to learn more and improve their achievement.

Schools need to improve the quality of their partnerships with parents, not only in financial affairs, but also in quality improvement programs. Schools and parents should share a common awareness about this. The existence of parents associations at schools shows that social networks at schools, especially between parents and schools, should be developed and managed. 
One way to better empower school committees is through corporate social responsibility programs with companies around schools. School committees can make partnerships with these companies so that they can also share the expenses of education. While many higher education institutions have taken some benefits of such programs, few schools have started partnerships. Such partnerships should not be limited only to the provision of infrastructure and learning materials; it should also cover some other needs such as scholarships, talent scouting, preparation for the final exam, and other non-technical needs.

\section{References}

Andreski, Stanislav. 1989. Max Weber: Kapitalisme, Birokrasi dan Agama. Yogyakarta, Indonesia: Tiara Wacana Yogya.

Barker, Chris. 2004. Cultural Studies. Yogyakarta, Indonesia: Kreasi Wacana.

Bourdieu, Pierre. 1986. "The Form of Capital." In Handbook Theory and Research in Sociology of Education, ed. John Richardson (pp. 241-258). New York: Greenwood Press.

Donkor, Anthony Kudjo. 2010. "Parental Involvement in Education in Ghana: The Case of a Private Elementary School." International Journal About Parents in Education 4 (1): 23-38.

Durkheim, Emile. 1973. On Morality and Society. Chicago: University of Chicago Press.

Fukuyama, Francis. 2002. Trust: Kebijakan Sosial dan Penciptaan Kemakmuran. Yogyakarta, Indonesia: Penerbit Qalam.

Georgiou, Stelios N. 2007. "Parental Involvement: Beyond Demographics." International Journal About Parents 1 (1): 59-62.

Haryatmoko. 2003. "Reproduksi Kesenjangan Sosial Melalui Sekolah.” Kompas, July 21, 4.

Jabar, Melvin Allena. 2010. "How Do Japanese Schools Promote Parental Involvement?" International Journal of Social Sciences and Humanity Studies 2 (1): 91-98.

Lawson, Michael A., and Tania Alameda-Lawson. 2011. "A Case Study of School-Linked, Collective
Parent Engagement." American Educational Research Journal 49 (4): 651-684.

Mulyasa. 2002. Manajeman Berbasis Sekolah: Konsep Strategi dan Implementasi. Bandung, Indonesia: Remaja Rosdakarya.

Pidarta, Made. 2004. Landasan Kependidikan. Jakarta: Rieneka Cipta.

Putnam, Robert. 1993. Making Democracy Work: Civic Traditions in Modern Italia. Princeton, NJ: Princeton University Press.

Rahmana, Ed. 2000. (Habitus $x$ Modal) + Ranah $=$ Praktik. Yogyakarta, Indonesia: Jalasutra.

Robet, Robertus, and U. Abdul Rozak. 2011. "Proses Sosial sebagai Medium Pembelajaran." Jurnal Sosialita 9 (1): 77-88.

Siskandar. 2008. "Peran Komite Sekolah dalam Meningkatkan Mutu Pendidikan." Jurnal Pendidikan Kebudayaan 14 (73): 664-681.

Sumintono, Bambang, Nora Mislan, and Hamdan Said. 2013. "School Committee: An Implementation of School Based Management Policy at School Level in Indonesia." Jurnal Cendekia 4 (1): 1-22.

Vellymalay, Suresh Kumar N. 2012. "Parental Involvement at Home and Student's Academic Achievement." International Journal of Social Science Tomorrow 1 (4): 1-7.

Wahono, Francis. 2003. Gelombang Perlawanan Rakyat: Kasus-kasus Gerakan Sosial di Indonesia, eds. Nur Kusuma and Fitria Agustina. Yogyakarta, Indonesia: Insist.

Yeni. 2008. "Pengaruh Visi Misi Sekolah dan Peran Komite Sekolah Terhadap Keefektifan Sekolah." Jurnal Pembelajaran 30 (2): 127-133.

Zamroni. 2007. Meningkatkan Mutu Sekolah: Teori, Mutu, dan Prosedur. Yogyakarta, Indonesia: PSAP Muhammadiyah. 